\title{
USING INNOVATIVE TECHNIQUES WHEN TEACHING UKRAINIAN TO FOREIGN STUDENTS
}

The paper aims to describe the peculiarities of using innovative and information technologies in general and video presentations in particular in the educational process of teaching Ukrainian to foreign students as well as to examine its effectiveness. Innovative methods for teaching languages at higher educational institutions make it possible to optimize the ways of presenting new vocabulary and grammar, dealing with monologue and dialogue activities, teaching writing and practicing pronunciation, etc. Multimedia presentations improve the teaching process providing information support in a visual form and help students learn the material faster and more efficiently. According to the research results, video presentations assist in increasing students' motivation and their academic performance. The study of the application of multimedia technologies during the lessons of Ukrainian as a foreign language has shown that the lack of its use in Ukrainian higher educational institutions is caused by the following reasons: low level of logistics (lack of equipment); the lack of criteria for assessing the efficiency of the technologies; low level of teachers' information competence and lack of their motivation to apply new methods and techniques in their teaching practice.

Keywords: innovation technologies, interactive education, multimedia, video presentation.

\section{Introduction}

A need for Ukrainian education modernization is explained by its integration into EU. The Ukrainian language for foreign students is a comparatively new discipline, which explains the fact of scientists' interest in implementing innovative teaching techniques in it. The issue of developing forms and methods of teaching Ukrainian as a foreign language, their permanent updating, adaptation to the new necessities of life lately has been among relevant in the field of higher education. Today a teacher of Ukrainian as a foreign language at university faces a problem of searching for ways of increasing the students' interest in the discipline, strengthening their positive motivation for learning.

Innovative educational methods are a research subject of A. Arlamov, M. Burchyk, I. Dychkivska, V. Zagvyazinsky, O. Zinchenko, A. Nisimchuk, L. Novikova, O. Piekhota. Informational support to education is presented in the works of V. Bykov, B. Hershunsky, R. Hurevich, M. Zhaldak, I. Zakharova, E. Mashbits, N. Morze, E. Polat, I. Trayneva, I. Robert and others. The implementation of interactive technologies was studied by V. Kotov, H. Lyimets, O. Pometun, O. Savchenko, and others. The development and application of teaching technologies were examined by O. Bespalko, M. Klarina, N. Kuzmina, B. Likhachev, B. Monakhov, H. Selevko and others.

The goal of a Ukrainian language teacher is to teach students to use the language in everyday life and professional communication. The application of innovative methodological approaches enables language teachers to implement and improve new methods, increases the efficiency of the educational process.
The paper aims to describe the peculiarities of using innovative and information technologies in general and multimedia presentations in particular in the educational process of teaching Ukrainian to foreign students as well as to examine their effectiveness.

\section{Research methods}

We used theoretical methods to study the scientific literature on the issue, as well as empirical methods (testing, interviewing) in order to examine the efficiency of using multimedia presentations at the lessons of Ukrainian as a foreign language and to find out if teachers use IT in their teaching practice.

\section{Discussion}

Innovative methods for teaching languages at higher educational institutions make it possible to optimize the ways of presenting new vocabulary and grammar, dealing with monologue and dialogue activities, teaching writing and practicing pronunciation, etc. The use of innovative technologies for teaching Ukrainian as a foreign language provides the access to new sources of information, increases students' motivation to receiving and processing professional information in the Ukrainian language, promotes the efficiency of independent work, gives new opportunities for creativity, makes it possible to implement new forms and methods of learning.

In education, the term "innovation" refers to new techniques or updating the existing ones. Innovative technologies contain the following approaches to the teaching of Ukrainian as a foreign language:

1. Interactive teaching methods;

2. The use of technical means of teaching (computer and multimedia, Internet) for knowledge assessment, storage and use of educational materials; 
To improve the quality of teaching and the acquisition of the necessary knowledge, abilities and skills, we believe that the most effective way is a combination of information technologies and interactive teaching methods.

The use of traditional and innovative technologies provides the educational process with the following significant characteristics:

1. Speech focus

2. Complex approach

3. Diversity of forms of work with students

Unlike traditional lessons aimed at mastering the knowledge, skills, and abilities, these classes take into account students' interests and inclinations.

During these lessons we combine the experience of traditional classes - acquisition of new material, assimilation, comprehension, summarizing, but in unusual forms.

Modern teaching technologies such as teamwork, making projects, the use of Internet resources provide individualization and differentiation of education taking into account the ability of foreign students, their level of knowledge [1].

The possibility of using Internet resources are enormous. Global network creates the conditions for getting various kinds of information required by students and teachers.

During the Ukrainian language lessons, the following didactic tasks can be solved with the help of the Internet:

- forming students' skills and abilities to read, using the materials of the global network;

- improving written language;

- enriching students' vocabulary;

- motivating students to study the subject.

P. Ragulin treats the term "multimedia" as a combination of computer technologies that use graphics, text, video, photo, animation, sound effects and qualitative soundtracks simultaneously. Multimedia technology is based on complex data combination and provides data processing (such as charts, images, documents, sounds, speech which create "multienvironment") [7, 125].

Multimedia provides greater opportunities if compared to traditional "chalk-and-talk" method. It promotes common work of both teachers and students [5].

The graphic audio and video information in multimedia programs has a great emotional impact, and its application makes students memorize the learning material better. In this regard the multimedia technology can be applied in the context of a wide variety of styles of teaching and can be used by different people both who prefer to learn through reading and who are better at hearing.

I. Molchanova, N. Timoshkina, A. Guchapshev state that in the process of oral presentation of the material students can perceive about 1000 units of information in one minute by listening to a teacher. Visual information increases the number of these units up to 100.000 . It is therefore absolutely obvious that we observe high efficiency when using multimedia in studying based on visual and hearing perception of the material $[4,151]$.
Multimedia programs can raise language teaching to a new level: informational exchange between students and technical system is carried out in a form of a dialogue, by the unregulated scenario that each time is built by a student in a new way, and computer technology itself organically fits into the classic system, develops and makes it rational, providing new possibilities for the organization of studying and assessing knowledge simultaneously, gives the real possibility of practical implementation of student-centered approach.

The use of multimedia technology has a positive impact on several aspects of the educational process:

- it stimulates the cognitive aspects of learning, such as perception and awareness of information;

- it increases motivation of students for learning;

- it develops the skills of collaboration and teamwork;

- it creates a deeper understanding of the studied material due to the combined effect of various types of information.

Multimedia technology helps a teacher of Ukrainian as a foreign language to improve the educational process, taking into account the interests and capabilities of every student, and to provide individualization and differentiation of training. The implementation of multimedia technologies creates conditions for interactive communication, which today is the most important component of the educational process. Using multimedia technology, the teacher may present information in a completely new and effective form, to make it more complete, interesting and close to the theme being studied.

According to our teaching experience, we noticed that multimedia presentations improve the teaching process providing information support in a visual form and help students learn the material faster and more efficiently.

According to V. Osadchyi, multimedia presentation is a program that may contain texts, photographs, drawings, charts, slide shows, sound design and voice-over, music, movies and animation, three-dimensional graphics [6]. Thus, the electronic presentation developed in Microsoft PowerPoint is a modern tool for representation of a variety of educational information in multimedia mode. Electronic presentation involves a set of slides, in which informative text is combined with graphics, pictures, sound, video and animated objects. It helps a teacher to prepare methodically justifiable and vivid visualization as well as to use it in a creative way at the lesson of the Ukrainian language.

The advantage of computer presentations is facilitating teacher's work and the possibility of ordering and keeping the material required for a certain lesson. Computer presentation cannot make up for the teacher's work with a blackboard, but it greatly simplifies the task of providing visualization. Its advantage is also the opportunity to return to the part of information that had not been learnt. Moreover, when commenting on the material on the slides, a teacher may elaborate on certain points, explain, comment on a figure. 
We developed presentations on the following topics when conducting lessons of the Ukrainian language with foreign students: "Contemporary Ukraine: geography, population, state language", "The Largest cities of Ukraine", "State Symbols of Ukraine", "Vinnytsia as the City Where I Study", "Traditions and Customs of Ukraine", "Major Holidays of the Ukrainians", "My University. The History of Pirogov National Medical University". In addition, we created some presentations to the textbook by L. Dmytruk, L. Matusevych "Prominent Scientists-Doctors" [3] used for foreign students studying Ukrainian, in particular "The Great Physiologist I. P. Pavlov", "D. K. Zabolotny as a Famous Scientist, Pedagogue, Public Figure", "M. M. Amosov as an outstanding surgeon, scientist, philosopher and writer".

Multimedia presentations should be used at the end of the lesson to consolidate the material or at the beginning to motivate the students for studying.

At the initial stage, foreign students should watch a presentation. After that it is necessary to answer the questions to find out if the students understand the key points of the topic. For example: watch the presentation "Contemporary Ukraine: geography, population, official language" and answer the following questions:

1. Where is Ukraine?

2. What countries does it border on?

3. What have you learned about the population of Ukraine and its area?

4. Which seas surround Ukraine?

5. What rivers flow through the territory of Ukraine?

6 . What did you learn about the regions and the cities of the state?

7. What did you learn about the symbols of Ukraine?

8. When did the image of the Trident appear?

9. What does the Trident symbolize? Ukraine?

10. What have you learned about the flag of

11. Why is the Ukrainian flag blue and yellow?

Before watching the video presentation, it is necessary to conduct preliminary work, in particular to provide students with the dictionary with unfamiliar vocabulary, for example, emblem, trident, image, falcon, symbol of unity, flag, Slavic. If students are well-prepared, have a great vocabulary, they watch a video presentation once. If they are not, they can do it twice. For the first time it is done in order to draw students' attention to the foreign language. The second time is aimed at the detailed acquaintance with the content and educational material of the video.

To consolidate the material, we conduct a short web quest "True or false" on the above mentioned topic (The answer has to be proved):

1. Ukraine is rich in monuments of history, culture, architecture.

2. There are 34 regions in Ukraine.

3. Kyiv was named in honor of the younger brother.

4. The main street of Kyiv - Khreschatik, the main square is The Independence Square.
5. Odessa was founded on the Dnieper river.

6. Zaporizhia has a special place in the history of Ukraine.

7. Kharkov was the first capital of Ukraine.

8. Ukraine is the biggest desert in Europe.

Homework for students involves creating their own video presentations about their native countries. For assistance, in creating their presentations the following questions can be offered:

1. Where is your country?

2. What states does it border on?

3. What seas and oceans wash its shores?

4. What major rivers flow through its territory?

5 . What is the population of your country?

6 . What is the language of your country?

7. Which city is the capital of your state?

8. When was your country founded?

9. What can you say about the administrative structure of your state?

10. What is the largest city of your country?

11. What recreational places are most famous in your country?

12. Describe the emblem and the flag of your country, please.

According to the research conducted in National Pirogov Memorial Medical University, within 3 years $81 \%$ out of 855 foreign students of the $1^{\text {st }}-2^{\text {nd }}$ years of study from 29 countries who took part in the survey, created original video presentations in electronic form, using multimedia technology, complementing the stories and comments. Only $19 \%$ of students used just photographs, drawings, text materials for creating a story about their native countries. So, it has been observed that the use of video presentations at the lessons of Ukrainian as a foreign language improves the learning process, as it encourages students to discuss them after watching. According to the observations that had been conducted during 3 years in 10 groups, where multimedia presentations were used, the students' academic performance was 30\% higher than in the groups of students in which they have not used this technique. In addition, the level of attendance in groups where they used video presentations was $20 \%$ higher than in the groups in which students have not used this method. So, it was concluded that the use of multimedia presentations has a positive effect on learning Ukrainian as a foreign language, and also contributes to a better memorization, increases the level of interest in the topic, develops creative thinking.

In order to find out if IT are used by Ukrainian language teachers in their teaching practice we have conducted a survey in National Pirogov Memorial Medical University at the Department of Ukrainian Studies. The study involved 855 foreign students and 21 Ukrainian language teachers participated in the survey. Teachers' survey has shown that $80.6 \%$ of them consider the use of IT significant and appropriate. $22.9 \%$ of teachers believe that all types of information technologies are effective, however, only $40.2 \%$ use all means in their teaching prac- 
tice. According to the results of testing, $79.1 \%$ of teachers use Internet, e-mail, web sites, and web conferences, $22.9 \%$ use electronic manuals and $7.1 \%$ apply multimedia means for teaching, $8.5 \%$ - information software systems. The survey of students has shown that only $38.8 \%$ of teachers use specialized software tools at their lessons.

The study of the application of multimedia technologies during the lessons of Ukrainian as a foreign language in Ukrainian higher educational institutions has shown that the lack of its use is caused by the following reasons:

- low level of logistics (lack of equipment);

- the lack of criteria for assessing the efficiency of the technologies;

- low level of teachers' information competence and lack of motivation.

\section{Conclusions}

Innovative technologies of teaching a foreign language in higher educational institutions provide an oppor-

\section{REFERENCES}

1. Balykhina, T. M., Hartsov, A. D. (2006). Informatsiya obutseniya yazykam: stanovleniie kompyuternoi lingvodidaktiki [Informatization in teaching languages: the development of computer linguodidactics]. Vyssheie obrazovaniie sehodhia - Higher education today, 4, 3238 [in Russian].

2. Dmytruk, L. I., Matusevyts, L. M. (2015). Vydatni naukovtsi-likari [Outstanding doctors-scientists]. Vinnitsa [in Ukrainian].

3. Malik, S., \& Agarwal, A. Use of Multimedia as a New Educational Technology Tool. International Journal of Information and Education Technology, 5, (Vol. 2). [in English].

4. Molchanova, I. A., Timoshkina, N. V., Huchapshev, A. S. (2005). Osobennosti sozdaniya multimediynykh program dlya mladshyh klasov s uchetom ikh vozrastnykh osobennostey [Features of creating multimedia programs for junior school students taking into ac-

\section{ЛІТЕРАТУРА}

1. Балыхина Т. М. Информатизация обучения языкам: становление компьютерной лингводидактики / Т. М. Балыхина, А. Д. Гарцов // Высшее образование сегодня. - 2006. - № 4. - С. 32-38.

2. Дмитрук Л. І. Видатні науковці-лікарі: навчальний посібник / Л. І. Дмитрук, Л. М. Матусевич. Вінниця, 2015. - 38 с.

3. Malik S. Use of Multimedia as a New Educational Technology Tool / S. Malik, A. Agarwal // International Journal of Information and Education Technology. October 2012. - Vol. 2. - No. 5.

4. Молчанова И. А. Особенности создания мультимедийной программы для учащихся младших класов с учетом их возрастных особенностей / И. А. Молчанова, Н. В. Тимошкина, А. С. Гучапшев // IT-инновации в образовании: материалы Всерос. tunity to improve ways of presenting grammatical and lexical information to students, help to practice monologue and dialogue speaking, pronunciation, enrich students' vocabulary. Multimedia technologies help a teacher of Ukrainian as a foreign language to improve the learning process, taking into account the interests and capabilities of every student, and to provide individualization and differentiation of training. Therefore, the application of innovative teaching techniques significantly improves the quality of educational material presentation, as well as its assimilation by students, enriches the content of the educational process, increases students' motivation, and creates conditions for closer cooperation between a teacher and students.

Further studies are planned to involve the examination of other innovative methods for teaching Ukrainian as a foreign language to students from abroad.

count their age characteristics]. IT innovatsii $v$ obrazovanii - Proceedings of the All-Russian Scientific and Practical Conference IT Innovations in Education (pp. 150-152). Petrozavodsk [in Russian].

5. Neo, M. (2007). Learning with Multimedia: Engaging Students in Constructivist Learning. International Journal of Instructional Media, 2, 149-158 (Vol. 34) [in English].

6. Osadchyi, V. V. (2012). Systema informatsiinotekhnolohichoho zabezpechennia profesiinoi pidhotovky maibutnikh uchyteliv $v$ umovakh pedahohichnoho universytetu [System of information technology support of professional training of future teachers in terms of pedagogical university]. Melitopol [in Ukrainian].

7. Rahulin, P. H. (2004). Informatsionnye tekhnologii [Information Technology]. Vladivostok TIDOT Dalnevostochnoho universiteta [in Russian].

науч.-практ. конф., 27-30 июня 2005г. - Петрозаводск, 2005. - C. $150-152$

5. Neo M. Learning with Multimedia: Engaging Students in Constructivist Learning / M. Neo // International Journal of Instructional Media. - 2007. - vol. 34. - 2. pp. 149-158.

6. Осадчий В. В. Система інформаційнотехнологічного забезпечення професійної підготовки майбутніх учителів в умовах педагогічного університету: [монографія] / В. В. Осадчий, за ред. С. О. Сисоєвої. - Мелітополь: Видавничий будинок ММД, 2012. - $420 \mathrm{c}$.

7 Рагулин П. Г. Информационные технологи: електрон. Учеб / П. Г. Рагулин. - Владивосток: ТИДОТ Дальневост. ун-та, 2004. - 208 с. 
Лілія Іванівна Дмитрук,

кандидат філологічних наук, дочент кафедри українознавства, Вінницький національний медичний університет імені М. І. Пирогова, вул. Пирогова, 56, м. Вінниия, Украӥна

\section{ВИКОРИСТАННЯ ІННОВАЦІЙНИХ ТЕХНОЛОГІЙ ПРИ ВИКЛАДАННІ УКРАЇНСЬКОЇ МОВИ ЯК ІНОЗЕМНОЇ}

У статті розглянуто особливості використання інноваційних та інформаційних технологій в цілому та відео презентацій зокрема для навчання української мови як іноземної студентам з інших країн в вищих навчальних закладах. в педагогічних цілях на основі інтерактивного навчання. Завдяки застосуванню інноваційних технологій можливості сучасних методів вивчення української мови як іноземної значно розширюються й стають більш різноманітними. Інноваційний підхід забезпечує позитивну мотивацію здобуття знань з української мови, збагачує зміст освітнього процесу, дає відчуття потреби в самоосвіті, сприяє розвитку творчої особистості, зрештою створює умови для більш тісної співпраці між викладачами та студентами. Результати педагогічного спостереження засвідчили, що використання мультимедіа презентацій та інших інтерактивних завдань сприяло підвищенню рівня володіння українською мовою студентів-іноземців, розвитку критичного та творчого мислення тощо. Інноваційні технологічні засоби викладання іноземної мови у вищій школі дають можливість удосконалити методи подачі граматичної та лексичної інформації, практики монологічного й діалогічного говоріння, навчання письма та відпрацювання вимови, постійного поповнення словникового запасу студентів. Мультимедійні технології допомагають викладачеві коригувати навчальний процес, ураховуючи інтереси й можливості окремих студентів, реалізувати особистісно зорієнтований підхід у навчанні й забезпечити індивідуалізацію та диференціацію навчання. Вивчення особливостей застосування мультимедіа технологій показало, що їх недостатнє використання при вивченні української мови як іноземної зумовлено низкою причин: низьким рівнем матеріально-технічного забезпечення; відсутністю критеріїв ефективності технологій; низьким рівнем інформаційної компетентності та відсутністю мотивації професорсько-викладацького складу.

Ключові слова: інноваційні технології, інтерактивне навчання, мультимедіа, відео презентація.

Reviewed by Doctor of Philology, prof. L. Azarova

Submitted on March, 29, 2017 